\title{
WACSeries
}

Volume 7, Issue 4 - March 2021

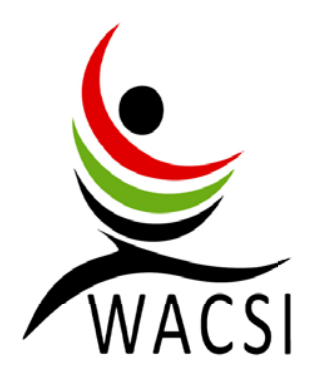

WEST AFRICA CIVIL SOCIETY INSTITUTE

\section{Youth Leadership in the \\ Public Service Sector in Africa: \\ Opportunities for Engagement?}

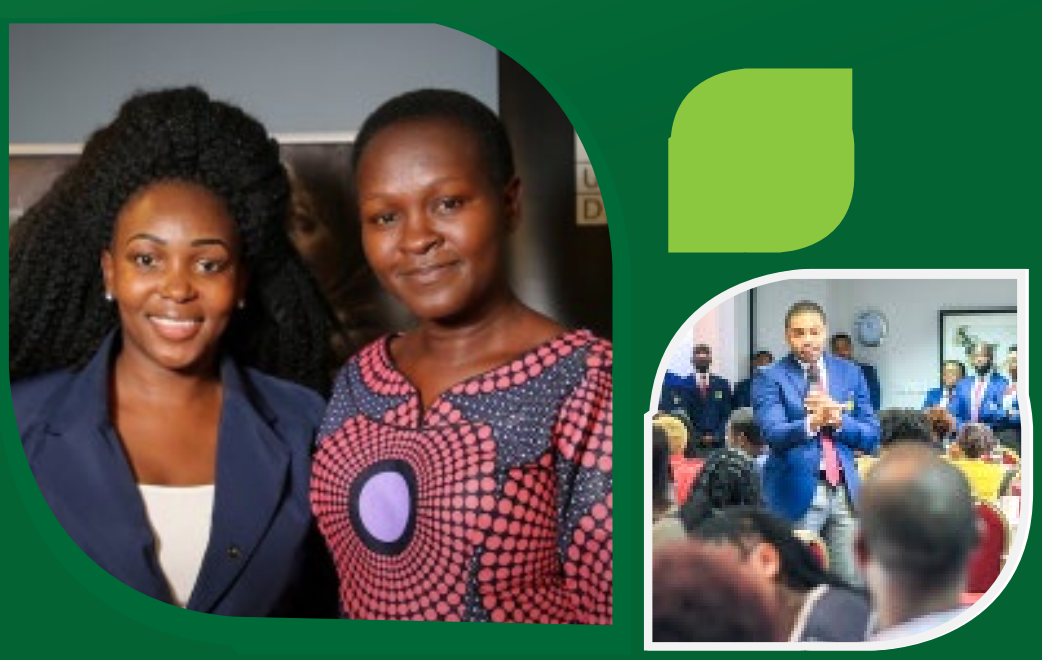

Metolo Foyet 
AUTHOR

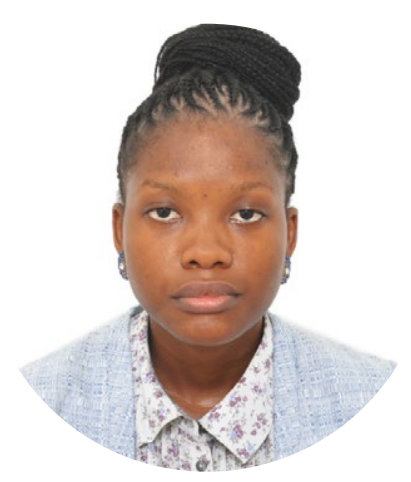

Metolo Foyet, is a politics and security expert, with keen interest in environmental and social safeguards thematic. She is a recipient of the U.S. Department of State's Young African Leaders Initiative (YALI) program, the West African Civil Society Institute (WACSI)'s Next Generation Internship (NGIP) flagship program, the Commonwealth100 Program. She is a member of the Francophone Network of Evaluation (RFE) and the Mandela Institute for Development Studies (MINDS) network. Published author with over hundred publications spread into academic papers, story books, blogs, articles and artworks. She graduated Magna Cum Laude from Lancaster University with a B.A in Politics and International Relations and with Honors from the Kofi Annan International Peacekeeping Training Centre (KAIPTC) with a M.A in Peace, Conflict \& Security. Metolo currently pursues a PhD in Environmental Management and Spatial Planning.

\section{Editorial Team}

Jimm Chick Fomunjong - Head, Knowledge Management Unit, WACSI

Christian Elongué Ngnaoussi - Programme Officer, Knowledge Management Unit, WACSI

\section{About WACSI}

The West Africa Civil Society Institute (WACSI) was created by the Open Society Initiative for West Africa (OSIWA) to reinforce the institutional and operational capacities of civil society in the region. WACSI also serves as a resource centre for training, research and documentation, experience sharing and political dialogue for CSOs in West Africa..

www.wacsi.org

\section{About WACSeries}

WACSeries are analytical periodic write-ups on topical themes and issues relevant to West Africa. These write-ups provide experts, researchers and practitioners a space to reflect, analyse and posit views and recommendations on emerging issues and debates. The WACSeries Issue Paper are thought provoking and intellectually engaging write ups that provide critical reflections and analysis of issues relevant to civil society and development in West Africa.

\section{Obectives of WACSeries}

- To raise awareness on key issues in West Africa;

- To generate debates and discussions on these issues;

- To proffer recommendations on civil society involvement in advocacy;

- To provide recommendations to policy makers. 


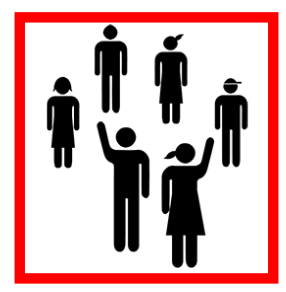

\title{
Youth Leadership in the Public Service Sector in Africa: Opportunities for Engagement?
}

\author{
Copyright WACSI 2021
}

All rights reserved. No part of this report may be used or reproduced in any manner whatsoever without written permission of the Institute except in the case of brief quotations embodied in critical articles and reviews. For more information write to:

\author{
West Africa Civil Society Institute (WACSI) \\ No. 9 Bamboo Street, East Legon \\ P.O. Box AT 1956, Achimota \\ Accra, Ghana
}

Email : research@wacsi.org
Tel : +233(0) 302550224

Cite this document as: Foyet, M. (2021). Youth Leadership in the Public Service Sector in Africa: Opportunities for Engagement?, WACSeries, Issue Paper, Vol. 7, Issue 4, West Africa Civil Society Institute, Accra, Ghana.

Disclaimer: The views expressed in this article are solely those of the author. WACSI does not take responsibility for the views expressed. 


\section{LIST OF ACRONYMS}

$\begin{array}{ll}\text { AIESEC } & \text { International Association of Students of Commerce and Economics } \\ \text { CIDA } & \text { Canadian International Development Agency } \\ \text { DAAD } & \text { German Academic Exchange Service } \\ \text { DANIDA } & \text { Danish International Development Agency } \\ \text { DRC } & \text { Democratic Republic of Congo } \\ \text { EFF } & \text { Economic Freedom Fighters } \\ \text { ICT } & \text { Information, Communications and Technology } \\ \text { IDEA } & \text { Institute for Democracy and Electoral Assistance } \\ \text { IDRC } & \text { International Development Research Centre } \\ \text { IOC } & \text { International Olympic Committee } \\ \text { IT } & \text { Information and Technology } \\ \text { ITU } & \text { International Communication Union } \\ \text { MIT } & \text { Massachusetts Institute of Technology } \\ \text { MRI } & \text { Magnetic Resonance Imaging } \\ \text { NATGEO } & \text { National Geography } \\ \text { NORAD } & \text { North American Aerospace Defense Command } \\ \text { PAIGC } & \text { African Party for the Independence of Guinea and Cape Verde } \\ \text { RFMEN } & \text { Francophone Network of Ministers in charge of the Digital Economy } \\ \text { SWAP } & \text { System Wide Action Plan } \\ \text { TED } & \text { Technology, Entertainment, and Design } \\ \text { UN } & \text { United Nations } \\ \text { UNDP } & \text { United Nations Development Programme } \\ \text { UNECA } & \text { United Nations Economic Commission for Africa } \\ \text { UNESCO } & \text { United Nations Educational, Scientific and Cultural Organization } \\ \text { UNFPA } & \text { United Nations Population Fund } \\ \text { USAID } & \text { United States Agency for International Development } \\ \text { WACSI } & \text { West Africa Civil Society Institute } \\ \text { YALI } & \text { Young African Leaders Initiative Programme } \\ \end{array}$




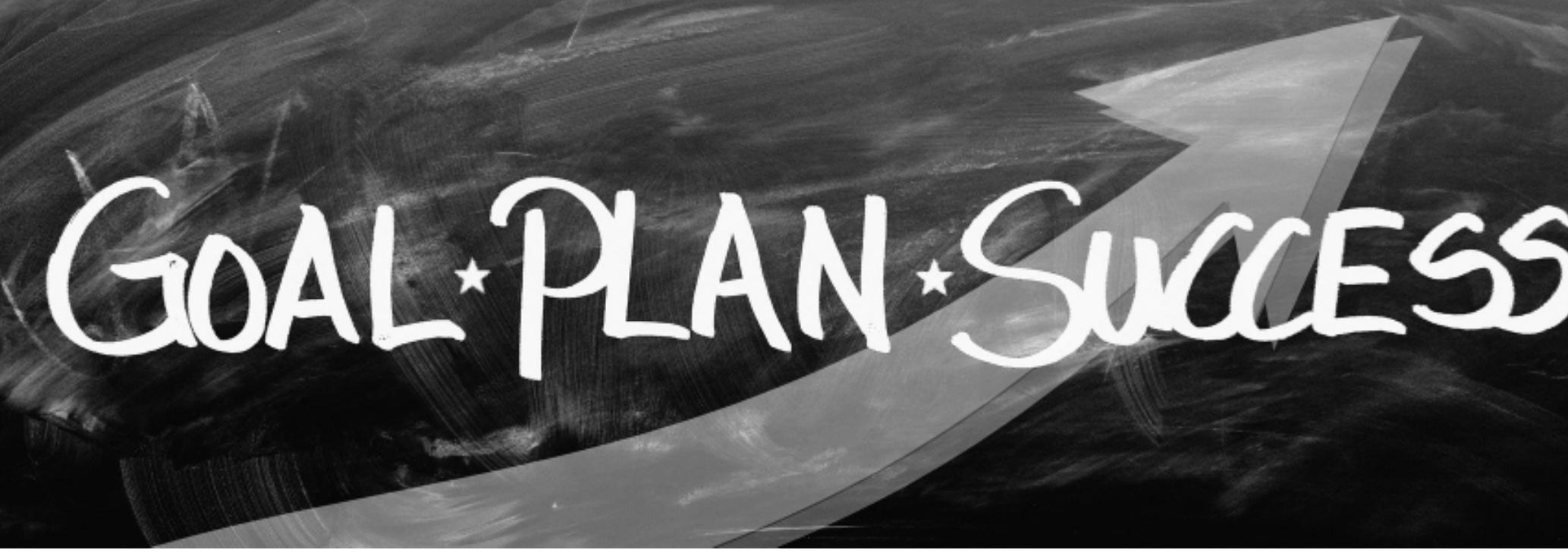

Photo from pixabay

\section{ABSTRACT}

The popular belief that the youth have not contributed much to national development in pre- and post-colonial Africa is grossly erroneous. As study has revealed that low level of active youth leadership on the continent is not due to lack of interest and effort on their part, but more because of the hostile political, economic and social environment, rigid structural barriers to youth mobility in politics and the economy in many West African countries. 'Harmful' cultural practices that require young people to defer to older ones make it hard for the youth to 'liberate' themselves (Sesay, 2014). Young people have also not been able to successfully organise themselves into workable pressure groups to effect positive political and economic change in their favour (Sesay, 2014).

There is a direct link between the plight of Africa's youth and the prevailing governance systems on the continent. It is essential to convince the old political class that youth empowerment and inclusion in governance processes is a sine qua non for overall national development, peace, and security. The demographic picture of youth makes it patently evident that engaging youth fully in development is not a matter of choice, but rather an imperative for national development. In not-so straightforward circumstances of political leadership as has been observed in Africa, only some form of affirmative action can take us anywhere close to achieving democratic equity for the youth in matters of political leadership on the continent. Given the way power is exercised, the power to change these cultural contexts considerably rely on head of states who in a snap of their fingers could change the deal if they had the will; and the king-makers and advisers of both the former and the latter, who often are more influential than the head of states themselves.

Equally, as today's old generation was yesterday's youth, it is imperative for young people to not become different as they grow older. Especially, as they experience the realities of power, they are encouraged not to become corrupt themselves and maintain integrity in order not to perpetuate the cycle. The youth must always remember Annan's saying: "you are never too young to lead, and you should never doubt your capacity to triumph where others have not." 


\section{Introduction

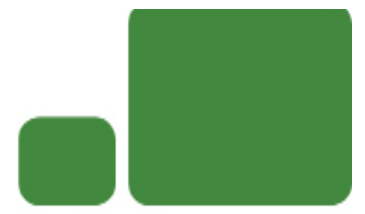

Are the youth as apathetic and disengaged as perceived in the African society? A closer examination of governance and political systems in Africa reveals this observation to be inaccurate. Analysis shows that the continent has had young leaders at state governance level from a time that preceded the independence. The youth have recurrently demonstrated willingness and an ability to contribute to the national development process from identification of issues to implementation and monitoring (UN, 2018). Yet, without the guidance, understanding, support, and recognition of government leaders and other decisionmakers, they have been unequipped for full participation in the decisions affecting their lives (Kura, 2008). Even though the youth have in a flattering manner been involved in leadership processes, they have been unable to translate their numerical majority consistently and suitably into youth friendly policies.

In 1994, the international association of students of commerce and economics (AIESEC) argued at length in defense of the idea that the 21st century society would need "dreams and courage" rather than a passive embracing of what the 20th century tended to naively accept as reality (Okombo et al., 2011). Interestingly, Martin Luther King Jr. had a dream (civil and economic rights and an end to racism in the United States), Nelson Rolihlahla Mandela had a dream (a free, prosperous, nonracial and just South Africa), Kofi Annan even highlighted the importance of dreaming by stating seventeen years ago (2003) that: without a dream, you will not get anywhere!

Young people have always been the trustees of dreams (imagining new possibilities) and courage (taking the necessary risks to try out the possibilities revealed in their dreams). Their creative force and immense resourceful aptitude for change are established facts that have been proven and endorsed throughout decisive moments of history, transforming what had seemed to be unchangeable realities. Continuously making enormous contributions to the improvement of life on the planet, there is hardly any function, be it cultural or political where youth have not played part: from leaders of crusades to sovereign monarchs, from prolific writers to media pundits. This capacity to dream of a better world of prosperity and equity of opportunities are needed in [state level] leadership (Okombo, 2011). Politics need to move from the recycling of old people to rejuvenation, balancing the weight of experience with the needs, energy, and innovative force of youth (UNDP, 2014).

Nevertheless, these truths, even though well ingrained in the African society's subconscious, continue to suffer a terrible indifference from the continent's leaders. In West Africa, youth contributions are not proportionate to their demographic weight as they have remained mostly excluded from the sub-region's important and critical socioeconomic decisions. Over the years, it has been noticed that youth involvement at the state governance level in places such as North America, Europe, and even Asia, a place perceived as conservatist, is been very promising. Sebastian Kurz (aged 33) and Syed Saddiq (aged 27), respectively the world's youngest-serving state leader (chancellor of Austria) and youngest cabinet minister in Asia (Malaysia) are great examples demonstrating how by supporting the youth into leadership roles, states can only but reap abundant fruits. Among the former's notable actions, figure a reform of Austria's social insurance system. Kurz amended his country's insurance law with the intention of improving services for the insured by modernising workplaces in Austria as well as discharging redundant functionaries. As for Syed, he succeeded, by a unanimous vote, in lowering the voting age, as well as the eligibility to contest in election in Malaysia to 18.

Accordingly, developing pro-youth policies and programmes will not be easy because of the reluctance of the older generation to give up their elaborate political, economic, and social privileges. In the following lines, the status of youth leadership at state governance level in Africa will be presented. An exposition of factors favouring youth involvement in leadership positions in the region will ensue, whilst emphasising on the actions of different stakeholders and the infrastructures existing to nurture and back African youth into playing senior leadership roles. Last but not the least, we will discuss challenges encountered by the youth on this feverish journey and explore general solutions as well as solutions by sector, notably from the government (public sector) and most importantly, from the youth itself. 


\section{I- A Historic Account of African Youth in Senior Leadership Positions}

Despite the overall unenthusiastic perception of the progress of youth leadership at the state level in West Africa, there have been records of heartening actions from different stakeholders.

On one hand, starting from the nascent consciousness that led to the formation of the Pan African Movement in the early Twentieth Century, "radical" African youth played pivotal roles in determining the future of the continent and its people during the penultimate days of colonial rule (Sesay, 2014). Most African participants at the 1945 Manchester Conference were in their youth and later founded political parties that became the arrowhead of the agitation for independence in their respective countries. Africa's Che Guevara - Thomas Sankara - was 34 at the dawn of his ascent to the head of the "Land of Incorruptible People". At 36, Kwame Nkrumah, Sheku Toure and Ahmadou Ahidjo were respectively appointed Secretary General at the above-mentioned symposium, first president of Guinea and first president of Cameroon.

At 30, Ingenious Amilcar Cabral founded a transnational party (African Party for the Independence of Guinea and Cape Verde - PAIGC), out of which his brother Luis emerged to become the first president of Guinea Bissau. Similarly, PAIGC remains one of Cape Verde's major party, where it acted as ruling party for almost two decades immediately after independence. At 32, tireless Amilcar went on to form, together with 34 years old Agostinho Neto and 28 years old Viriato da Cruz, the political party that has ruled Angola since the country's independence from Portugal in 1975.

In Sierra Leone, Valentine Strasser had just turned 25 when he spectacularly seized power from Joseph Momoh during the 1992 coup. Yahya Jammeh was 28 when he became Gambia's leader, after he overthrew Dawda Jawara in a bloodless orchestration. Liberia's Samuel Doe was only 29 when he became head of state in 1980, after leading a violent takeover that killed William Tolbert Jr. and ousted his government from power. In 1966, Nigeria's Yakubu Gowon ascended to power at 32, following a countercoup that turned in his favor. A year later, Odumegwu Ojukwu led the Biafran secession, aged 34.

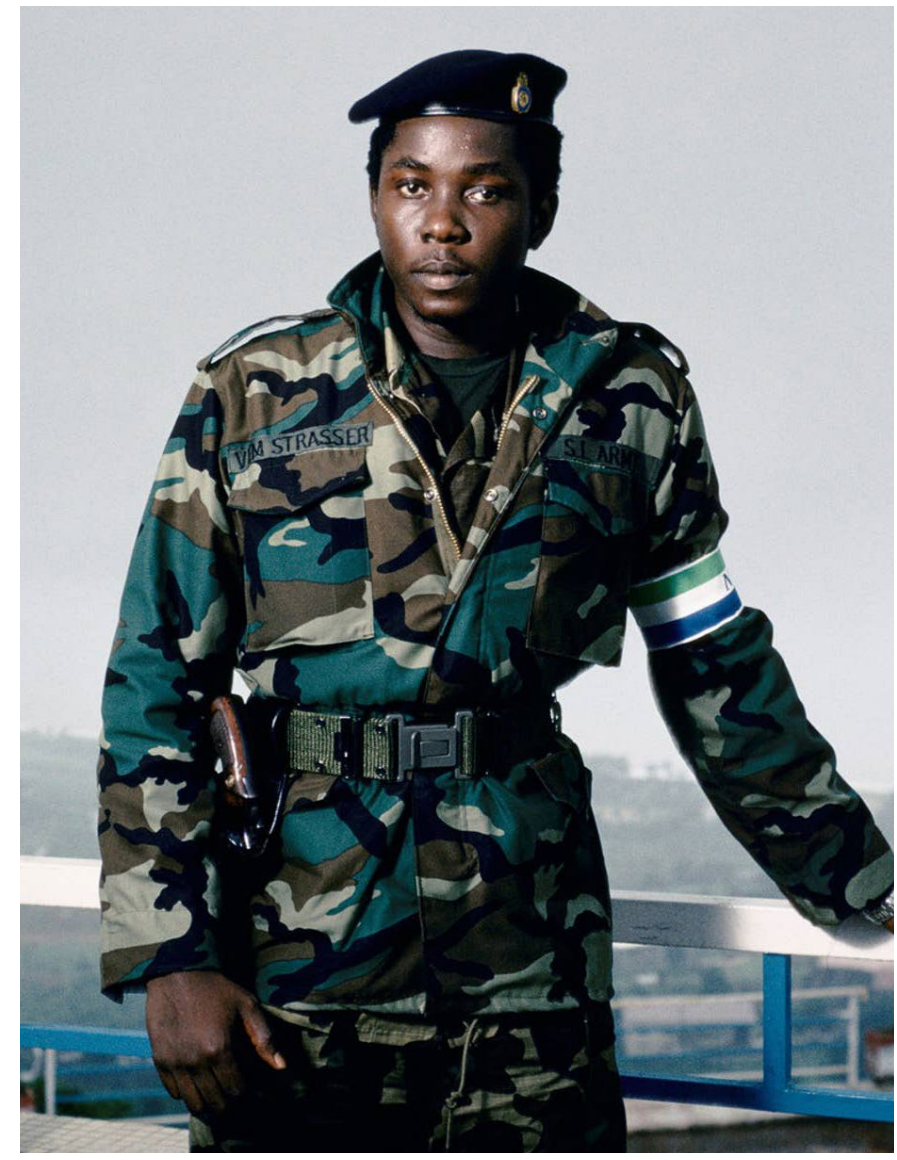

Photo from https://newscentral.africa/

On the other hand, most long-serving African leaders have in fact been introduced to the public's eye at a noticeably young age, however in ways that did not give room for the majority to appreciate that aspect of African governance. Examples that are most suitable here are Paul Biya and Theodore Obiang Nguema, who came into government in their late 20 s and 30 s respectively, and have been in government till date, taking senior positions until their ascent to the presidency.

In other parts of Africa, remarkable Tom Mboya was 23 when entrusted by Jomo Kenyatta to lead Kenya's independence party (Kenya African Union), after the latter's arrestation in 1953. Five years later, he chaired the Nkrumah-convened All-African People's Conference. At 33 , he consecutively led two ministries. Muammar Gaddafi was 27 when he started governing Libya. And even though his almost half of a century reign was infused with several positive achievements both for his country and Africa (and maybe the world if looked deep into), his historic departure and the indescribable scene that followed in his country clearly did not give room to impartially appreciate the vision whose foundations he established when he was still a young leader. Omar Bongo was 32 when he started ruling Gabon. 
In 1998, Burundi's late president Pierre Nkurunziza was appointed deputy secretary-general of a major political party at the age of 35. Prince Makhosetive was crowned King of Swaziland and hence head of the country's royal family in 1986, at barely 18. Letsie III was only 27 when he took the crown of Lesotho. Aged 29, Joseph Kabila became the president of the Democratic Republic of Congo (DRC), after his father's assassination in a coup at the peak of a calamitous civil war. Such a cataclysmic entrance in the political arena obviously did not favour him in the eyes of critics. And his forced exit in 2019, in the middle of a stagnant-like civil war, a manifest political instability and after 18 years of governance that do not seem to have attracted applauded assessment, visibly cannot help to fairly appreciate the fact that he did become president at an age many till date are still struggling to make ends meet. Cameroon's Paul Biya was just 35 when serving as Secretary-General of the Presidency. At 45, current youngest head of state in Africa and former media entrepreneur Andry Rajoelina had to seize power in a widely condemned military coup. Yet twelve years earlier, he was already mayor of Antananarivo at the age of 33, and that, without having to stage a coup.

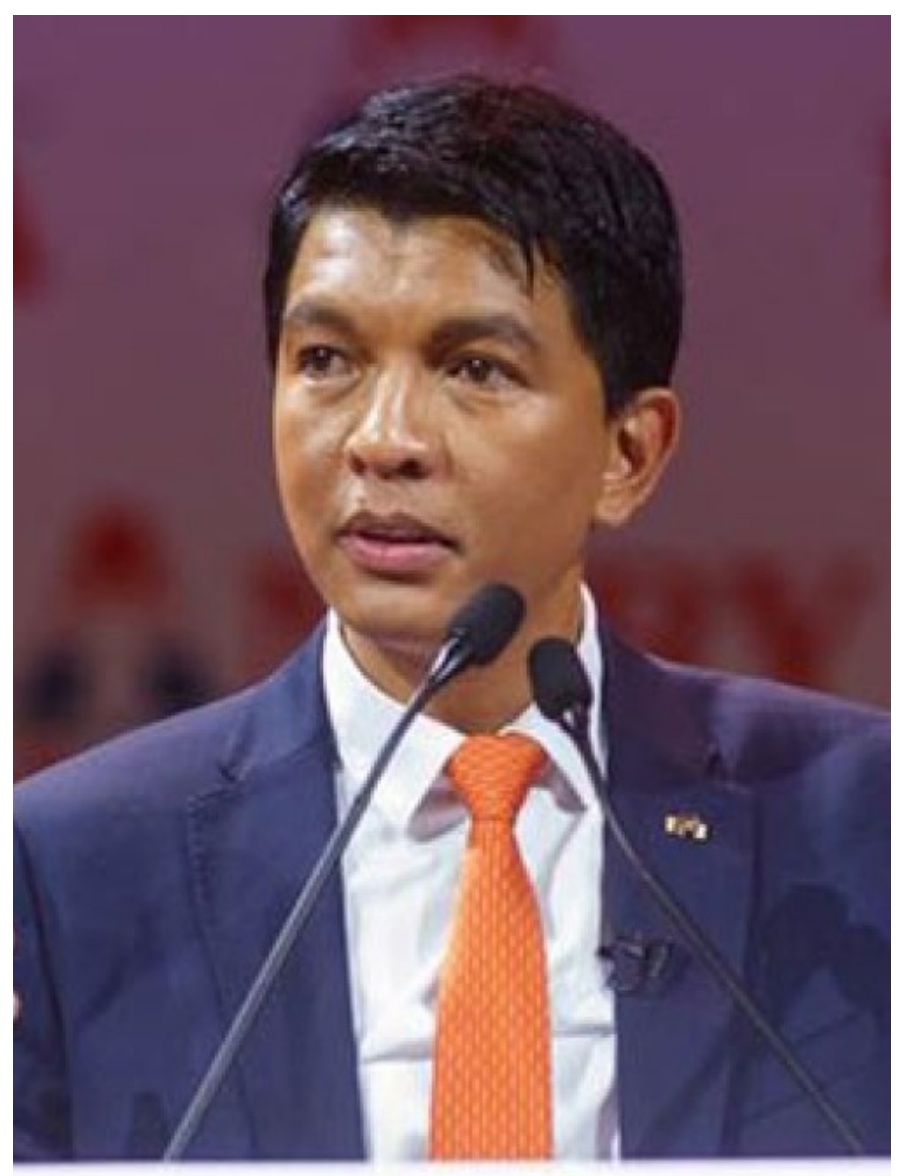

Photo from https://www.therahnuma.com/
Immediately, three ironic assumptions flow from these lines. Firstly, it seems as if in Africa, when one is made leader at a young age, his death is automatically destined to occur either in a precipitated or an undesired way. Secondly, if one is young and ambitious, he must reach his goal either through a dramatic military blow or any other "undemocratic but accepted" performance. Thirdly, it appears as if Africa's revered leaders, the likes of Mandela or Nkrumah, failed at grooming dauphins and were instead replaced by individuals tagged as kleptomaniac and megalomaniac.

Moreover, there has been an emergence of westerndeveloped leadership programmes directed towards youth in the south, raising along the line anxious debates on the issue of talent theft (Sako, 2002). Nevertheless, these remarks do not annul the fact that there has been a visible progress in brain drain reduction. A component of this progress is that African youth are increasingly alert to brainwashing as they have grown aware of the opportunities their continent offers and the role they have to play in its transformation. Even though some of the young people who go through the following capacitybuilding programs end up (in) directly serving the interests of the sponsoring-nations, many more make the choice of adapting the knowledge acquired to the African context and transforming African narratives by staying in the continent to build legacies in their own little ways. These youth programmes are sectioned into the following categories:

Fellowship programmes: these are series of online and/ or very intense onsite workshops that enable young people with identified abilities to develop their leadership skills through practical experience. Notable examples are the British-sponsored Queen's Young Leaders programme and the American-sponsored Mandela Washington Fellowship for Young African Leaders (YALI) programme, among others.

Scholarship-designed cultural exchange programmes such as AIESEC, the Turkish International Olympics, the German academic exchange service (DAAD), the Britishsponsored Chevening, the abundant Chinese-sponsored scholarships, and the American Fulbright, just to cite these. 


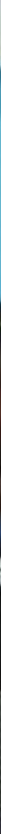

Photo by YALI via opportunitydesk

Young professional programmes: such as that of the United Nations, the World Bank, the African Union, the African Development Bank, the West Africa Civil Society Institute (WACSI), the German Africa Kommt, among others. In this category, also figure youth camps (e.g. international youth camp), youth summits (e.g. one young world summit), young leaders dialogues (e.g. World Economic Forum's Young Global Leaders), bilateral young leaders programs (e.g. French-African young leaders programme), programmes per industry (e.g. young physician leaders program).

Equally, some western nations channel these programmes through cultural institutions that aim at exerting soft power (Bodomo, 2009; Pan, 2013; Lanshina, 2015; Blond, Sim \& Noyes, 2017; Rahman, 2019). Some of these institutions include embassies, centers (e.g. Confucius, American, Goethe and French Institutes) and international schools such as Turkish, British, and recently Lebanese schools, among others. The African Leadership Academy is among the very few listings of African organisations that have a focus on youth leadership development for youth aged 15-18 years old. In Ghana, Lead Afrique equally offers leadership programmes to pupils and students alike. In Liberia, the Young Political Leadership School Africa (YPLSA) organized by Naymote Partners for Democratic Development and which was initially designed for Liberians, has now gone Africa wide and some alumni have become parliamentarians (in Liberia).

In Cameroon, the Network for Solidarity, Empowerment and Transformation for All (NewSETA) implements the REPAIR programme (Hachelaf, 2020), an annual youth peace and democracy series intending to deepen young people's knowledge about peace and democracy while fostering a culture of active youth participation and leadership.
The UN SWAP, the Commonwealth Plan of Action for Youth Empowerment (Tracey \& Kahuthia, 2017), the UN Environment Programme's Tunza Youth Advisory Council, and the Oxfam international youth parliament are other examples. In the last decade, a number of bilateral and multilateral agencies (including DANIDA, NORAD, USAID) have developed youth-focused strategies setting out their programme for youth. CIDA has made youth one of their three core strategic priorities, and youth is also a core priority for the Ford Foundation, the UNFPA and IDRC. Finally, websites also serve as medium for spreading these opportunities. Prominent websites are opportunitydesk, opportunityforafricans, scholarship365, youthop and opportuniyforyouth, among others.

Accusing West Africa of not favouring youth leadership would be an understatement, as the issue is two folded. On one hand, the youth is under-represented in the leadership sphere as it is of today. On the other hand, how the existing very few is treated, the purpose for which they are placed into leadership roles and the routes through which they arrive as such positions all raise a lot of curiosity. However, another component of the abovementioned progress stresses on narratives about efforts made by a number of governments in the region to reduce the youth leadership gap at the state level.

Numerous governments are gradually getting the message by allowing youth to do what it does best: digitisation. Digital economy has rapidly become a pillar symbol of governance and female leadership in the West African region as promising profiles are emerging. This new wave of youth leadership in the sub-region would be said to have probably started a decade ago, with the appointment in 2013, of the striking Cina Lawson as Minister of Post and Telecommunications of the Togolese 


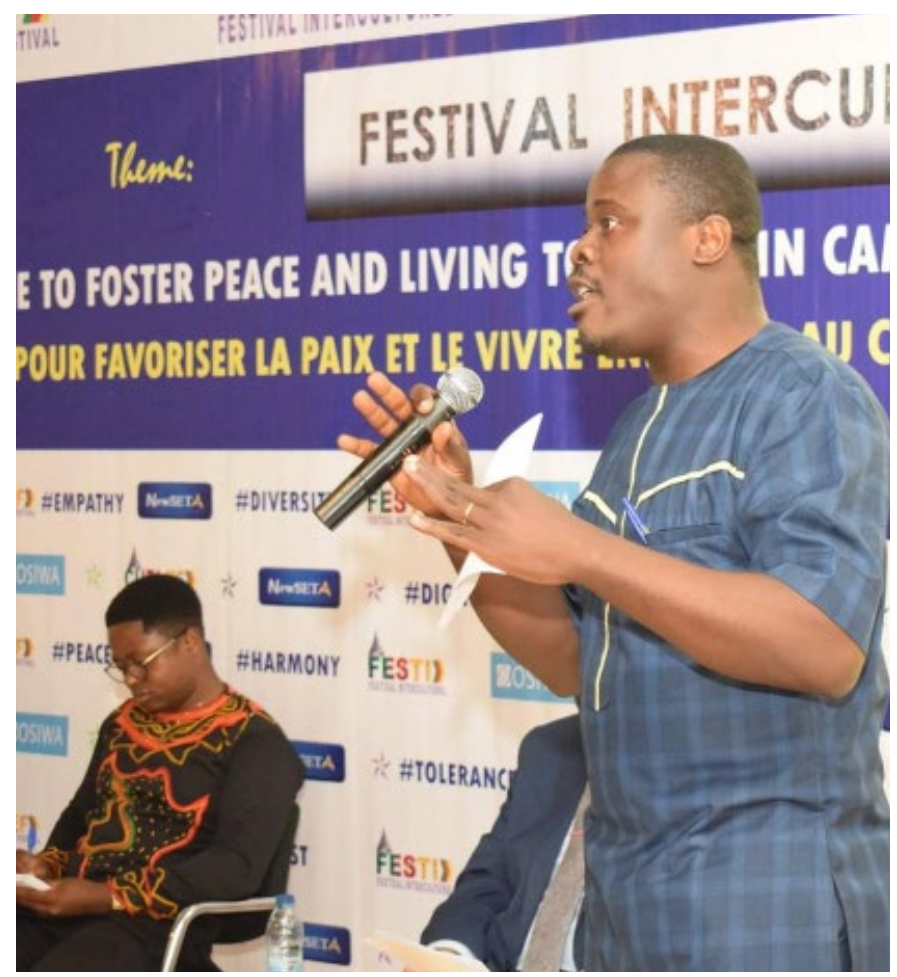

Photo by NewSETA

Republic. While in office, the 37 years old result-oriented Lawson contributed to the development of Togo's digital administration and the reduction of the digital divide in her country by integrating information and communication technology (ICT) in the Togolese education curriculum. From 2013 onwards, her portfolio expanded to include digital economy and technological innovation. Currently the Togolese Minister of Post, Digital Economy and Technological Innovation, she has been acclaimed and rewarded worldwide for her outstanding contribution to the development of the country's digital economy and ICT sector. Moreover, Togo is a particular example to emulate, as the country is becoming a leader in the subregion in promoting women's leadership. The most recent appointment (October 2020) of the 29 years old Mawunyo Mila Aziable as Minister Delegate to the President of the Republic in charge of Energy and Mines is a milestone worth celebrating.

In 2008, at only 27, Malema was already the president of the powerful youth wing of South Africa's ruling party, the Action National Congress. And even though he wields enormous power in South Africa's politics (played pivotal role in the election of President Zuma in 2009), Julius remains a controversial figure known for his inflammatory rhetoric. Expulsed form the party in 2012, he formed the Economic Freedom Fighters (EFF) party, contested the May 7, 2014 general elections and won 25 seats in the South African Parliament.
At 36, skilled Telecommunications and ICTs professional, Aurelie Adam Soule leads Benin's Digital Economy and Communications sector since October 2017. The president of the Francophone Network of Ministers in charge of the Digital Economy (RFMEN) played an active role in the participation of Benin and Africa in the 2015 ITU World Conference.

Mali's current minister for digital economy and planning, Kamissa Camara, is the youngest minister of the country. She was appointed two years ago (2018) as Mali's minister of foreign affairs, at age 35. Before her appointment in 2018, the diplomatic advisor to Mali's president, Ibrahim Boubacar Keita, founded and led the Sahel Strategy Forum.

33 years old Bogolo Joy Kenewendo is Botswana's youngest minister. Leading the country's Trade and Industry Investment since April 2018, Bogolo is an economist of career. 2016 was a great year for Kenewendo, as she became fellow of the Foreign and Commonwealth Office International Leaders Programme and joined Botswana's parliament by presidentially nomination. A 2009 youth delegate at the 64th Session of the United Nations General Assembly, she presented a statement of African youth to the Secretary-General of the United Nations. The 2011 hosted-by-Michelle Obama young African women leaders' forum to which she participated inspired her to co-found Molaya Kgosi, a mentorship programme aimed at mentoring and exposing young women to experienced and successful women in Botswana. The following year, Bogolo was honoured with the Ten Outstanding Young Persons award by the Junior Chamber International Botswana. She is currently a member of the High-level Panel on Digital Cooperation, co-chaired by Jack Ma and Melinda Gates, and appointed by UN Secretary General Antonio Guterres (2018).

Former Olympic swimmer and most decorated Olympian from Africa, Kirsty Coventry has been heading Zimbabwe's ministry of Youth, Sport, Arts and Recreation since 2018, then aged 35. World record holder and member of the International Olympic Committee (IOC), she is also the co-founder of an academy that nurtures youth through sports. Kirsty equally chairs the body that represents Olympic athletes worldwide (IOC Athletes' Commission), and is subsequently a strong and influential figure in the world of sports worldwide. 
Previously Senior Executive Secretary, Special Assistant to the Minister of State and Chief of Staff, and Assistant Minister of Foreign Affairs, 30 years old Abratha Patience Doe is, since 2019, Liberia's Deputy Chief of Mission to the United States. The young lady is a veteran youth, women and civil rights activist and former Member of Parliament of the Liberian Senate.

33 years old David Moinina Sengeh is Sierra Leone's Minister of Basic and Senior Secondary Education, since 2019. David was only 31 when he joined the Office of the President of Sierra Leone as the country's first-ever chief innovation officer, in May 2018. Among the records of the current youngest minister of Sierra Leone, figure Lebone Solutions, a start-up he co-founded with the aim of developing inexpensive batteries from microbial fuel cells. The Lemelson-MIT/TED/Obama/NatGeo Fellow is also a musician who has interest is Artificial Intelligence (AI) and Biomechatronics. He used Magnetic Resonance Imaging (MRI) to map amputee's limbs, then assessed where artificial materials could create pressure points, and used 3D printing to generate new sockets.

Co-writer and economic commentator Vera Daves de Sousa is Angola's current minister of Finance. Appointed in 2019 at age 35, Vera caught the attention of politicians in her country through her intervention in various media in her country. Archer Mangueira, looking for young talent to help start debt trading on the Angolan stock exchange, invited her to join the company he chaired: Capital Markets Commission. She has been replacing Archer ever since whenever he moved to higher positions. First at the lead at the commission, and now at the ministerial position Archer held before being appointed governor in Angola. Vera is the first woman to be appointed to this post in the country's history.

For his part, the youngest minister in the Algerian government, Yacine Oualid, was appointed deputy minister for startups in the Algerian government on January 2, 2020. The 26 years old Web developer and selftaught digital marketing specialist is well known in the Algerian IT development community as he has founded the first Algerian private host Smart Solutions Hosting and two start-ups in the fields of digital intelligence and marketing, cybersecurity, cloud computing and digital marketing and digital intelligence.

On January 2, 2020, ambassador of the L'Oréal-Unesco Foundation "For Girls in Science", Maha Issaoui, was appointed Secretary of State to the Minister of Health of Tunisia. At 32, the researcher and lecturer is the youngest minister of her country and one of 10 women ministers in Habib Jamli's government (4 ministers and 6 secretaries of state). Parallelly to speaking in middle and high schools to encourage girls to pursue scientific careers, Maha is a blogger and human rights activist who considerably intervened during the Arab Spring.

At 23, Mércia Viriato Licá is the youngest Member of Parliament in the history of Mozambique. Entering office on January 13, 2020 as part of the 9th legislature of the country's National Assembly after the general elections in October 2019, Mércia has for workforce the education and improvement of the living conditions of the disabled. Mercia, who does not have upper limbs, stood out from the crowd thanks to two sentences said to Mozambican President Filipe Nyusi: "I am not different," and "I am not special"! The brave lady, who is not only an inspiration for disabled people, but also for any young girl and anywhere in the world, wishes through her new position, to fight against discrimination and harassment towards disabled people, which she paid for while growing up. She strongly plans on leading by example through her mandate's achievements, so as to demonstrate to the Mozambican population made up of $60 \%$ of young people, that anything is possible if they believe in themselves. Ms. Viriato's candidacy was proposed in 2019 by the Mozambican president. She had written to him in 2018 via facebook to plead for the improvement of living conditions and access to education for people with disabilities in Mozambique.

At 34, Mamfe-based tycoon Ashu Priestly Ojong had gained one's spurs. Full product of the Cameroonian educative system (undergraduate degree in Philosophy from the University of Dshang), the late Ashu, recent Mayor of Mamfe, employed over 50 Cameroonians through ventures he launched at age 20 . Before becoming mayor, following the February, 9, 2020 twin municipal elections, he served as 2nd Deputy Mayor for his municipality. This promising young man was shot and killed by Ambazonian fighters on May 10, 2020, whilst leading Cameroonian soldiers to Eshobi, his village located at $8 \mathrm{kms}$ from Mamfe (National Telegraph Africa, 2020).

Filsan Abdulahi, 28, is the youngest member of the Ethiopian government. Since March 12, 2020, she has been the minister in charge of women, youth and children. Before her appointment, she was a UK-based speech-language pathology consultant. The owner of 


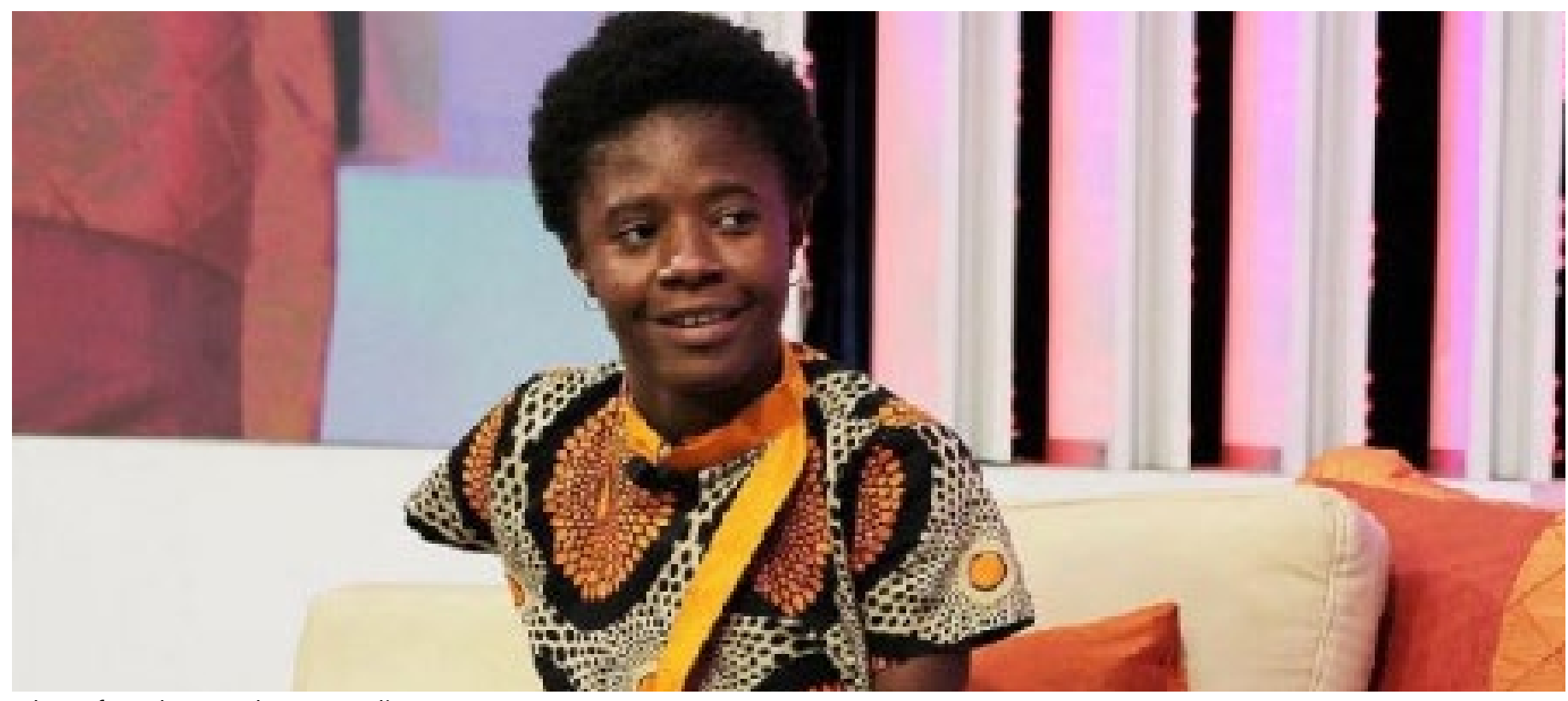

Photo from https://thepressradio.com/

new-found and first private and independent television channel "PeaceTV" is equally the initiator of the "Nabad (peace in Somali language) project", a campaign launched for peace and reconciliation among various ethnic groups in Ethiopia.

At 23, Namibian Emma Theofelus takes the title of the youngest minister and youngest female minister in the world. On March 23, 2020, she was appointed vice-minister of information and communication technologies of her country. Africa's and Namibia's youngest minister and Member of Parliament has been serving since December 2017 as member of the board of directors of the national higher education council in Namibia. She has equally been since the same time, youth ambassador to the Namibia National Commission for Unesco. Impressive Emma has been very proactive in promoting youth leadership in her country. At age 16 , she was already the junior mayor of Windhoeck, the former head of the Windhoek City Junior Council has a track record of encouraging members of the youth council to educate their peers on the importance of civic participation. Before her appointment, the lawyer of career and co-founder of the Namibian chapter of the Southern African Alliance for Youth Employment was vice president of the Children's Parliament and served within the Directorate of Legal Services of Namibia's Ministry of Justice.

These appointments have received a lot of praise as most political positions were until then given to older people. However, technically, only 6 individuals among the list above can be considered youth. Although the rest of these individuals may no longer be in the youth bracket
(18-30), it is important to observe that the presidents who nominated them have demonstrated the willingness to exercise positive change, and this alone, is encouraging and hopefully promising as Africa is expectantly watching for the rest of current African presidents and upcoming ones to emulate similar nominations in their respective countries.

It cannot be helped but noticed that most of these nominations are directed towards women, as a way of filling the gender gap in governance. The gesture is certainly worth praising. Nevertheless, in as much as the increased number of women in elected positions to date demonstrates women's ability and their engagement, it also shows the way institutionalised gender bias continues to lead to their under-engagement.

Women in leadership, and as a matter of fact, the youth as well, have acquired the positions they hold through various ways, which include election on merit, election because of connection to a powerful family member (father, uncle, husband or brother) or the connection of one of the previous to a powerful authority, token appointment, pelvic power, a friend or "a friend's friend", other influence and competence, and/or mastery of the game of politics the male way. To enhance leadership and good governance as envisaged by the constitution, there must be a transformation of prevailing attitudes, beliefs and practices concerning leadership, gender and age relations and a commitment by the women, men, and youth of Africa to good governance. 


\section{II- Challenges Youth Encounter in Taking up Leadership Roles in the Region}

Despite the fact that there are records of youth exercising senior leadership roles in Africa, this has not been translated in youth friendly policies. The problem with the concept of participation is that it can be given different meanings by different people in positions of power. Most of these people, both from opposition camps - Ahmed Ould Daddah (Mauritania), Henri Konan Bédié (Ivory Coast), Cellou Dalein Diallo (Guinea Conakry), Messan Agbeyome Kodjo (Togo), Hama Amadou (Niger), Joseph Nyumah Boakai (Liberia), Charles Walker Brumskine (Liberia), John Fru Ndi (Cameroon), Etienne Tshisekedi (DRC), Afonso Dhlakama (Mozambique), Kizza Besigye (Uganda) (most of whom have been opposition leaders for at least two decades) - and incumbents' offices, are old individuals who have passed the retiring age. It has equally been observed that many of the youth who served in government from the 80 s (50-plus today) do not have ideas that are different from the leaders they served. They equally may have been appointed into government because their parents or godfathers lobbied towards that end.

Also, there are cultural norms that still favor hierarchical relationships between the old and the young, and they have extended into the realm of government operations. The cultural pervertisation of the word "respect", which translates into the "godification" of the "elders" into beings whose words, actions and demeanors should never be questioned is gravely to be blamed. The unwillingness of political "grand-fathers" to prepare (through good mentoring) and leave the stage for young ones, together with the lack of self-confidence and 'harmful' cultural practices that require young people to defer to older ones make it hard for the youth to "unleash" themselves. Youth are plagued by problems of attitude that can be attributed to the gerontocratic and conservative "adultleaders". Imbued by patronising sentiments, the latter have "legalised" the act of taking the youth for granted; and consequently, have been unappreciative of their issues and potentials.

According to Bamfo (2018), if African nations can take advantage and provide adequate education suitable to respective market needs, and grassroot-oriented public policies, $\$ 500 \mathrm{bn}$ a year could be added to its economies for 30 years, which is the equivalent of $1 / 3$ of Africa's GDP [emphasis added]. Most governments have not only

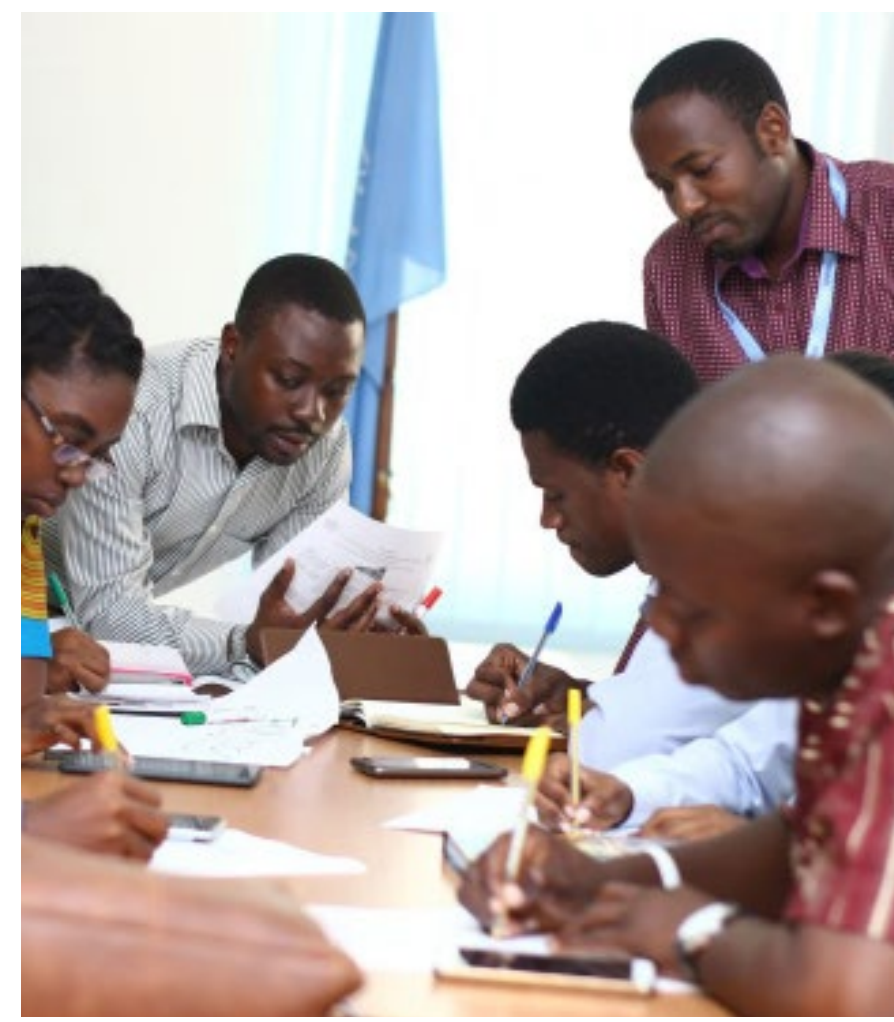

Photo from https://www.afrinype.org/

failed to provide constructive outlets such as recreational facilities for youth, but they have also proclaimed laws that keep "youth from streets" from surviving and away (whereas the "streets" constitute an important sphere of youth social participation and integration). Furthermore, they have even taken repressive measures to the effect of labeling the youth with derogatory names. The youth are either described as weapon of mass destruction or seen as lazy, as reportedly done by former presidents of Nigeria, Cameroon and Zimbabwe (Akwagyiram, 2018).

The youth leagues of various political parties operate on ad hoc basis. Although party constitutions and bylaws recognise them, the reality shows they are yet to be institutionalised. While parties have mechanisms and provisions for allowing their senior party officials (usually 35-plus) to get direct (uncontested) nomination as party candidates during general and special elections, there are no similar arrangements for their youth-league officials (Okombo, 2011). Most West African nations do not have a policy that guarantees youth nomination in a local authority or parliament by the political parties (Kanyadudi, 2010).

Therefore, the youth have very little chance of succeeding in such a competitive game without a special party intervention by way of affirmation - either by special clearance at the time of party nominations, wired by party support financially and morally at the time of campaigning against candidates from other parties; or by nomination 
into party allocations for nominated parliamentary and local leaders. It is worthy to stress that in West Africa, even the "affirmed" are fooled as they are chosen for the sole purpose of acting merely as messengers or agents of their older counterparts who enjoy real decision-making power. For example, a genuine case of youth leadership is when the youth can be said to be in charge as the key decision-makers, not when the party's "bosses" simply give the youth (often negative) assignments to carry out for the benefit of the "elder" bosses.

Nevertheless, it is increasingly believed that more young people should involve into politics to act the change and change the game. The big four (government, civil society, private sector, academia), change agents (prolific writers, artists, youth movements, string-pullers, king-makers) and other influencers should treat generational inequality with the same sense of urgency as other forms of inequality, accelerating efforts to introduce youth quotas to guarantee a minimum share for young candidates on party lists, parliaments and other decision-making institutions ( $25 \%$ of the candidates must be 30 years or younger).

In West Africa, people under the age of 30 are rarely found in formal political leadership positions. In a third of countries, according to the UNDP (2012), eligibility for the national parliament starts at 25 years or higher and it is common practice to refer to politicians as "young" if

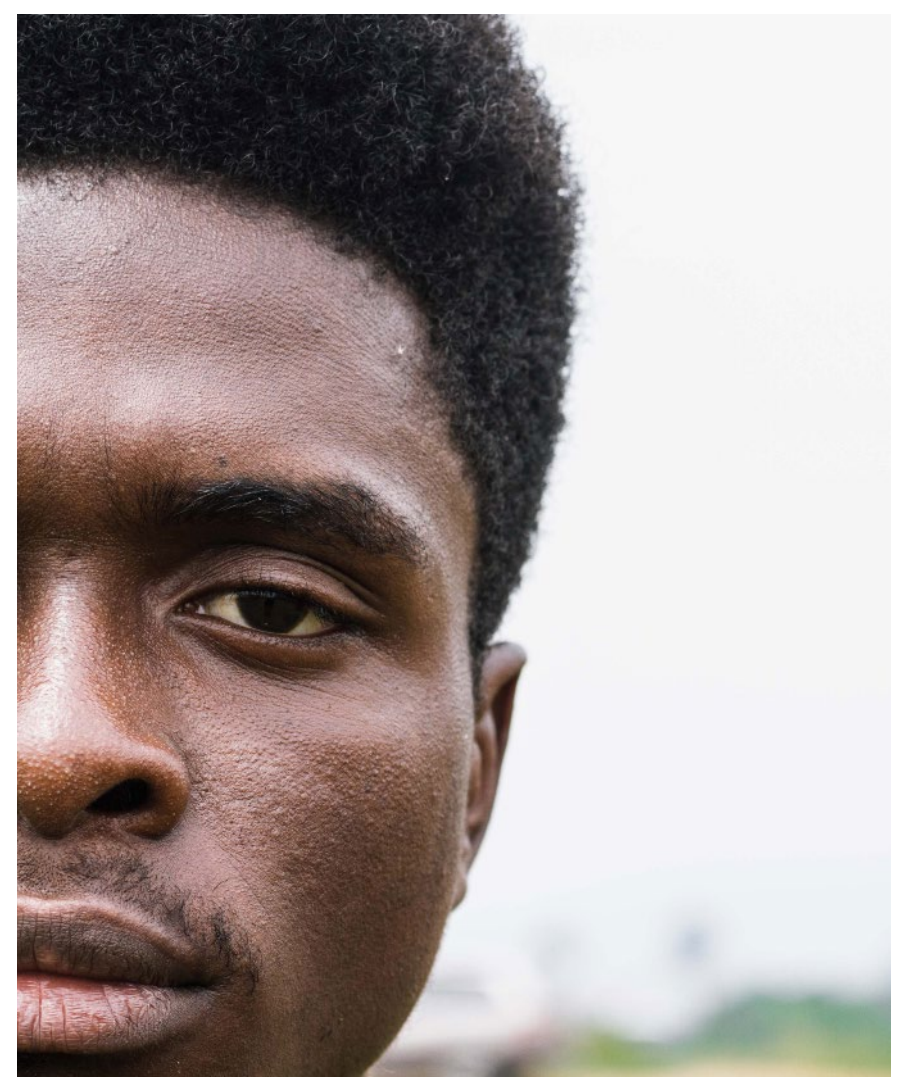

Photo by Adeboro Odunlami on Unsplash they are below 50 years of age. This already established and tailored definition of youth is one of the fundamental sources of youth leadership crisis as has been observed over the years. Action therefore urges towards the stretching of age eligibility to age 18 (the onset of the age of majority in most African constitutions).

Several other factors aid in explaining the low level of active youth leadership (Jalata, 2014) in existing structures in Africa:

Lack of encouragement mainly characterised by parental objection and/or cultural or religious prohibition: parental influence is a significant dynamic in the African setting. Children are raised to believe making their parents proud is their premier duty. If you have grown up listening to your parents, when they say no, you do not question it. Youth in Africa are self-censored from childhood and were brought up to fear politics. Religious restrictions also limit the youth as politics is often seen in religious circles as a haram activity only sinners involve in.

Low or lack of exposure to opportunities: neighborhoods are often portrayed as incubators of trouble and violence that offer youth a limited perspective of the opportunities they can gain in life. Experience has shown that a great factor favoring those of the youth that is actively involved in leadership is the quality of the entourage they have surrounded themselves with. Inequity systemically limits the opportunities that might have helped individuals to better their situation. Most youth in unhealthy neighborhoods do not have a sense of belonging and conversely feel unsafe to move around in ways that would positively benefit them. In general, they believe that 'nobody cares' about their voices, lives and contributions, especially underscoring the gendered inequalities and lack of recognition for female contributions to local civic engagement (Dlamini et al., 2015).

Low self-esteem and gender/age bias: equally, the youth express concern that people often think that "he is a small boy/she is just a girl" and "they believe a young person, or a girl can't make a difference." Low expectations hence contribute to low self-esteem and setting for lower than our abilities can do. Lack of role models can also affect self-esteem as often young women (for example) do not see other women acting in ways that suggest strength and confidence; rather, they are constantly exposed to images of fragile, sub-servient and helpless women. 
Lack of focus/time: moreover, young people easily get distracted or sidetracked by friendship and romance. These hyperactivity and multitasking skills act as a doubleedged knife and could be seen as flaws by authorities who are more inclined to work with people capable of finishing what is started.

Additionally, there is a blatant mistrust in political parties. By dint of witnessing repetitive unfulfilled political promises, and votes that do not count at elections (implying electoral frauds occurring even under civilian rule), youth have come to cultivate a strong cynicism about politics.

For the still-hopeful ones, the main Cerberus is the financial investment that goes into it. Finding the patronage thus become the ultimate aim, to the detriment of the youth's integrity. "Positioning" is an extremely capital-intensive affair in African politics, and only those with money or political god fathers can stand for elective positions and hope to win. Even after they are elected or appointed into important positions, they remain beholden to their "money bags". On one hand, patrimonialism negatively affects youth involvement in leadership as it does not harness full potential of youth in political participation on the continent. The reflection of current representatives of African leadership in the mirror that is this witty African proverb : "where you sit when you are old shows where you stood in youth", has made this mistrust particularly alarming as even promising youth of today are being meticulously watched because of the sentiment that they can only be assessed once they taste power.

On the other hand, political corruption and the cost of elections is a main barrier to and an ethical dilemma for youth leadership in Africa. This leads among others to the use of illicit financial resources, which alone is bad foundation to build a responsible political career on, as illicit funding limits effective representation and the desire for change among young people.

The youth are also subject to active manipulation through various forms of media, and often find it difficult to navigate political processes, including practices within political parties, in order to make a substantive and sustainable difference to their communities and countries (IDEA, 2018). According to the latter, the regional director of Transparency International Chantal Uwimana indicated that the illicit flow of resources is essentially corruption disguised as commercial activities, noting that over 60 per cent of flows involve multinational companies, and such flows often include the financing of politicians as a way of exercising control over resources. She added that only 5 per cent of illicit flows are categorised as corruption while 35 per cent are categorised as criminal activities (trap through which the reality of the cost of elections often drives people into for sponsorship purposes).

Other challenges broadly include bad governance (which enables insecurity; shields corruption; disregards the issue of illiteracy and promotes social exclusion); "neglect by society" as the issue of youth leadership is pumped into the ears of populations who have for priority their daily survival; exploitation through labor and abuse of their courage in militant and insurgent groups and as instruments of political struggle though they end up being the least beneficiaries (Kura, 2008).

\section{III- What Can be Done?}

\section{In General}

Six specific routes have been followed by the youth that landed high public seats in Africa. They are either;

- from the diaspora, having evolved at key positions in renowned multinationals or international organisations;

- activists, having advocated for human rights, contributing to formulation of policies to advance the development of a cause (children, women, youth, etc.);

- athletes and world record holders, having brightly represented their countries internationally;

- brilliant minds who have stood out by excelling in a field, developing an original and sustainable solution;

- very dynamic individuals who have caught the attention of the leader or his entourage and/or

- from the close circles of the leader or his entourage.

Accordingly, to overcome the specific challenges facing the youth, there needs to be reform of political parties and strategies need to be introduced to regulate the flow of resources into political parties. It is important to acknowledge that very often, political parties in Africa are ideologically weak and do not have the basics of what is needed to be a good political organisation. The consequence of money having great influence on politics is that parties do not have credible members' lists. Equally, there is no internal democracy as decision-making is reserved to an exclusive membership whilst most members are excluded and serve as fillers and accessories. Building 


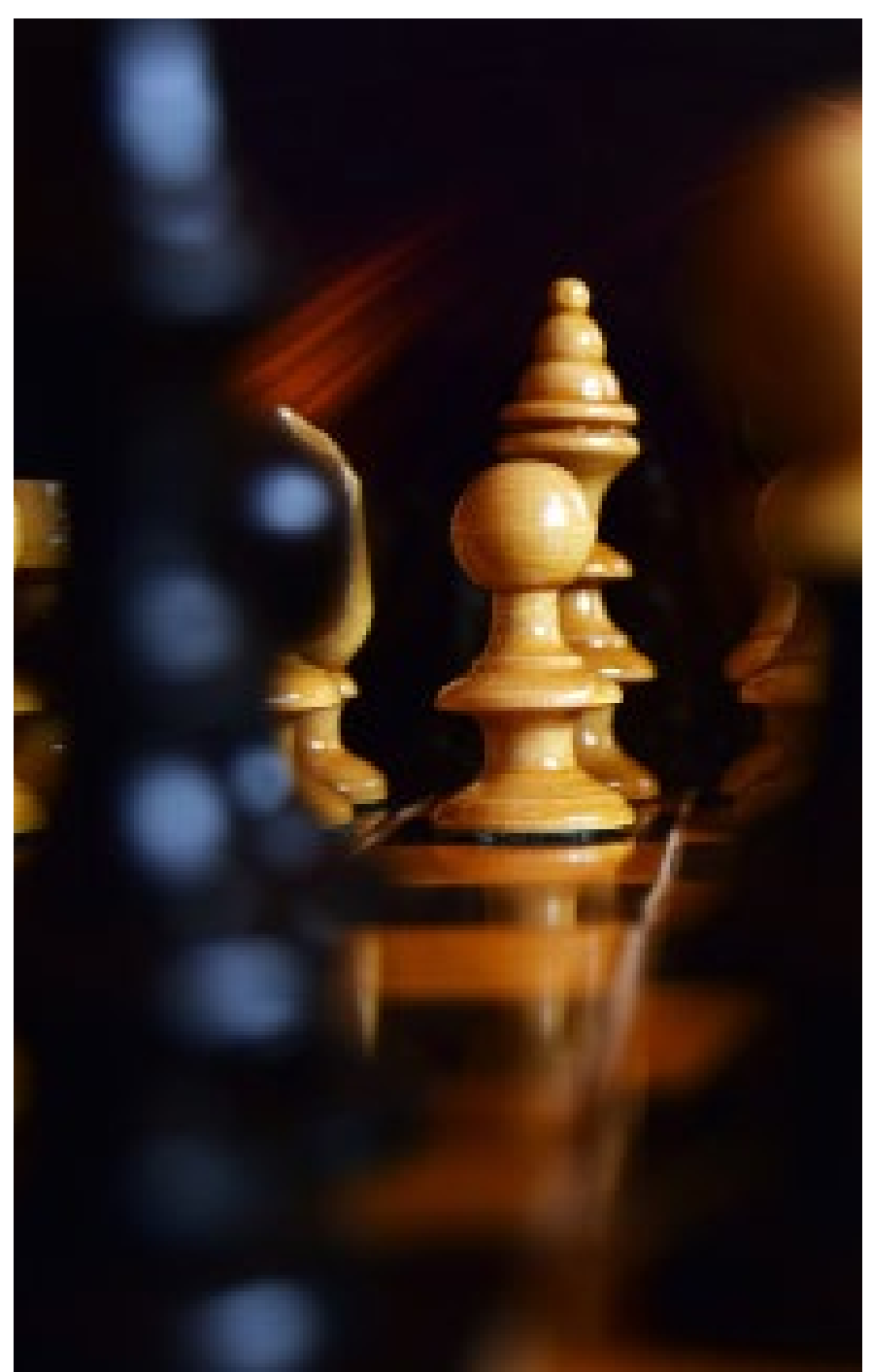

Photo from https://drift.eur.nl/

political consciousness is vital and young people can be at the forefront of this task. To counter illicit financial flows, there is a need to change the ingredients for success. It has to be policies and not money that pushes people into politics.

This requires initiatives on the constant renewal of parties and to enable ongoing experimentation on doing better politics. Attention is also needed on introducing and implementing regulations on the financing of political campaigns. Public funding of political parties could be a key consideration for the future. Because technology is hackable, blockchains offer the advantage of transparency as it allows easy traceability of resources and transactions. Similarly, appreciating the financial situation of young people who enter politics means channeling support towards these bright minds so that they can remain outside of the influence of money in politics.
In addition, the representation and participation of youth women's in politics are vital to the fight against the adverse facets of money in politics as youth women can be at the forefront of bringing evidence of these (not so) new forms of corruption into the public sphere.

High turn-over and lack of institutional mechanisms present key challenges for inter-ministerial coordination on youth affairs. Inter-institutional coordination, both across different ministries and between the central and subnational levels of government, is essential to ensure a clear division of roles and responsibilities and align the objectives set out in national youth strategies and sectoral. This can be done by establishing a well-resourced secretariat in the ministry responsible for coordinating youth affairs to avoid that this task will be added on top of the existing responsibilities exercised by civil servants.

This secretariat will establish inter-ministerial committees (or working groups for specific topics) and designate focal persons for youth affairs in all ministries and other government bodies. Each working group for specific topics will be chaired by youth focal points of ministries with corresponding portfolios. And inter-ministerial committees will include focal points and members of the ministry in charge of youth affairs. Clear action plans for each level of government (national, regional, and local) and thus each focal point will be developed (Restless Development, 2014). Engagement and coordination with civil society organisations (csos), youth networks and other partners can now be improved, and the secretariat will design a joint action plan to clarify mandates, ensure ownership and monitor the work of the coordination mechanism based on clear objectives and targets. Finally, templates and joint standards can be used to promote a common approach to monitoring and evaluating the outcomes of government action for young people. Since most prime ministers in Africa appear to play a passive role in governance, to save cost, they can be assigned the portfolio of Intergovernmental Affairs and Youth as done in Canada - supported by a Prime Minister's Youth Council (PMYC) which could serve as secretariat or advisory body on matters pertaining to the nation's youth.

Hopefully, as the people of Africa become more conscientised, we will see more of pan-african leaders in the modern sense who will not only know what ruling system works best according to their nation's context, but will also ensure their people are economically empowered. The likes of Nyerere or Lumumba fought for political 


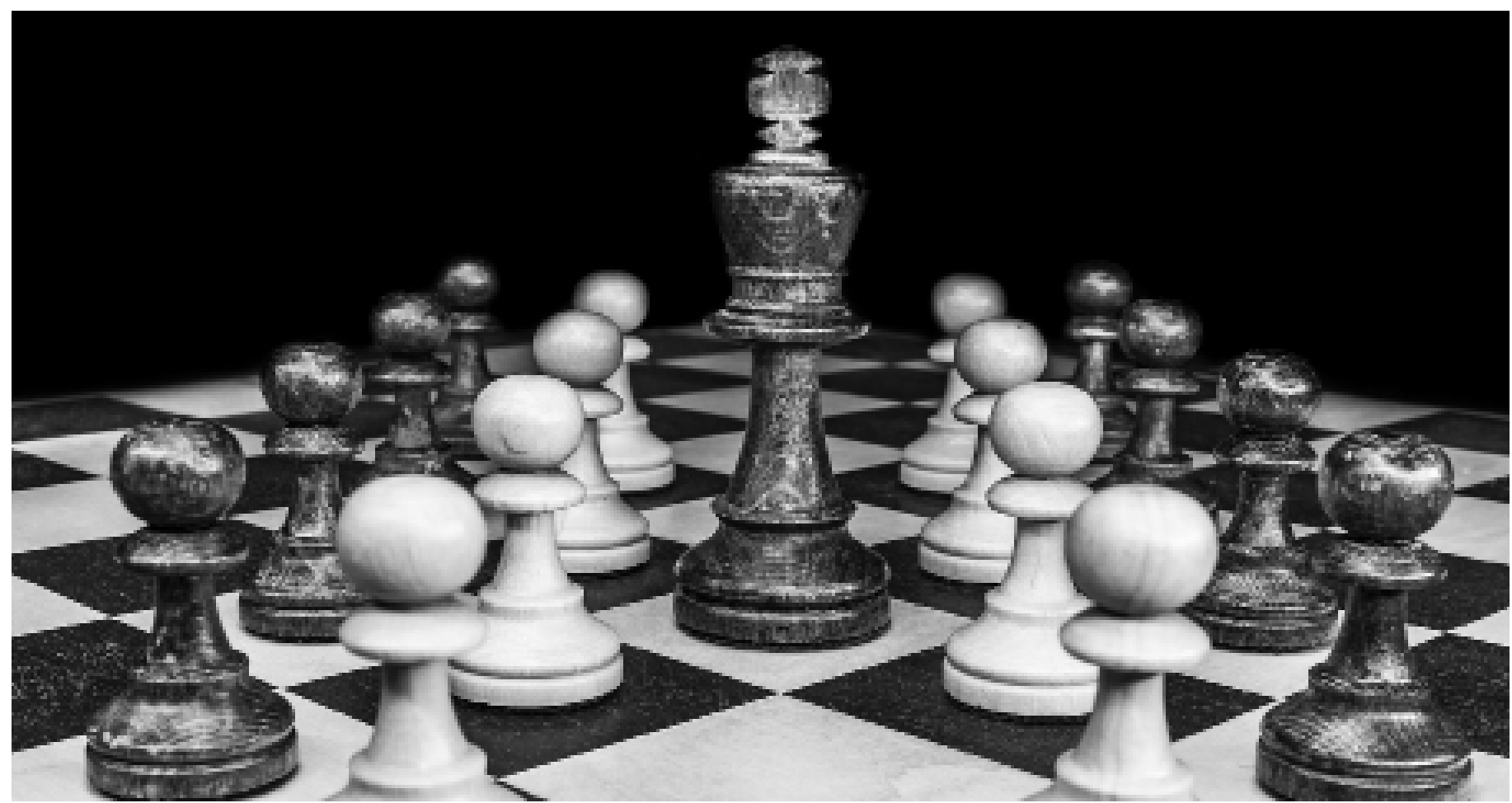

Photo from pixabay

independence, did their best to entrench the values of "true democracy" in the continent but had little or untried economic blueprint on the ground to empower the people economically after independence (UNECA, 2013). South East Asia's governance has grown better as they have advanced their economies through healthy rivalry between countries in the region and collaboration with former colonisers. This was possible by ceasing divisions, aids, handouts, and outrageous embezzlements, all habits the youth could find innovative ways to depart from.

\section{By the Government}

Governments are the largest change-makers in society and as such are perceived to be major stakeholders in resolving issues such as the object of this paper. Shifting to e-governance (WPAY, 2006) is a concrete way to engage more youth in public leadership as it facilitates the accessibility to government services, allows greater public access to information, offers a wide scope of possibilities to engage in political activities (online forums, electronic petitions, political blogs, etc.) and makes governments more accountable to citizens. By enhancing the government's ability to request, receive and incorporate feedback from constituents, policy measures can be better tailored to meet youth's expectations. E-governments can easily collect, monitor, and use data to improve government interaction with the youth. Essential services for young people can be delivered using mobile technology as a job search tool, providing skills training and job matching, promoting positive lifestyle choices and behavioural change, and introducing smart commute interventions to securitise strategic layers (public transport, health, shelter, food, etc.)

Constitutions in the region make provision for the inclusion of the women's voice in the leadership, and empower women as citizens, thereby increasing their sense of selfworth and capacity to challenge beliefs and practices. Therefore, it is important to include capable young women in leadership, not only because it is the right thing to do, but mostly because women bring different perspectives, values, and skills to leadership. They are considered less corrupt, more consultative, and therefore more likely to contribute to good governance (Oduol, 2011). Moreover, women have demonstrated their ability to influence in the private and public spheres.

According to Oduol, women are seen to make better leaders because of their preference for collaboration and consultation, and for the tendency to approach matters from the heart. Even though reasoning with the heart is seen as erroneous by many, it happens to be exactly what is needed if indeed the wellbeing of the people was the ultimate priority of our leaders. Because of their caring nature, women lead with a conscience and are more committed and accountable to the agenda of the people. 
Therefore, if elected, women leaders would focus on the right use of resources, through commitment to service (Oduol, 2011). Oduol continues by adding this should result in a reduction in excessive abuse of office and resources and a tangible output of activities that concern the citizens such as food security, health, and education. Moreover, Oduol adds, women leadership also results in the protection of the interests of special populations such as persons with disability and the elderly through priority setting. Suffice to analyse trends on how pivotal young men and women leaders have been to the success of political parties during elections.

\section{By the Youth}

Young people have the most considerable role to play in strengthening their image. And in order to attain the goal of making their acceptance into political sphere a norm, unity is key. The securitisation of democratic spaces should be led by youth, as a way of ensuring institutions work as intended. Youth need to be able to understand they are the most attractive alternative to current leadership. As history has it, the topmost causes of leadership decline have mostly got to do with a breach in integrity, hence the need for the youth to put in place systems to detect poisoned opportunities susceptible to stain their integrity. Token participation is meaningless, as it does not empower young people to influence outcomes and achieve real change. Most of the youth in Africa can list excuses on why they are not ready for leadership at the country level. They face a major challenge of having to convince everyone, including fellow youth, family and current opinion and political leaders. As youth develop plans to take up leadership in the new order, they must expect to adjust along the way as they navigate the journey to the finish line. This requires shrewd planning and the conscious restructuring of the community. As Oduol suggested for women, the youth equally needs to utilise John Maxwell's PLANAHEAD acronym explained as follows: •Predetermine your course of action; $\bullet$ Lay out your goals; $\cdot$ Adjust your priorities; $\cdot$ Notify key personnel; -Allow time for acceptance; $\cdot$ Head into action; $\cdot$ Expect problems; $\cdot$ Always point to your successes; $\cdot$ Daily review your progress (Clement et al., 2014).

Moreover, the youth must distance herself from the handicaps that are under-engagement and selfcensorship. When offered exposure, many are cautious of presenting their real views about the political situation due to fear of possible implications of their political judgments. They omit critical insights they would have otherwise expressed in private. The abusive usage of selfcensorship as a survival tool by many of the youth visà-vis the authorities and other partners who might not share their vision is significantly paralysing the progress of youth leadership. The language must be witty, whimsically refined in a way that still allows for messages to be transmitted, rather than be choked at the youth's own expense.

With the wide range of opportunities available for youth leadership, it is clear that many want to take up leadership positions hoping that freedom and power await them. These youth think that because positions have been guaranteed by law, there will be reduced opposition and plenty of rewards. Yet, youth leadership demands constant sacrifice, perhaps more so than the older folks. It is therefore particularly important that every young person seeking to lead at the national level and above stops to reflect on the price they are willing to pay if they are to become effective leaders. Although pursuing their stated visions and rallying people around these remain critical, the youth will find it difficult to give up so much and to make great sacrifices without growing bitter or resentful if they do not consciously prepare to serve with wisdom.

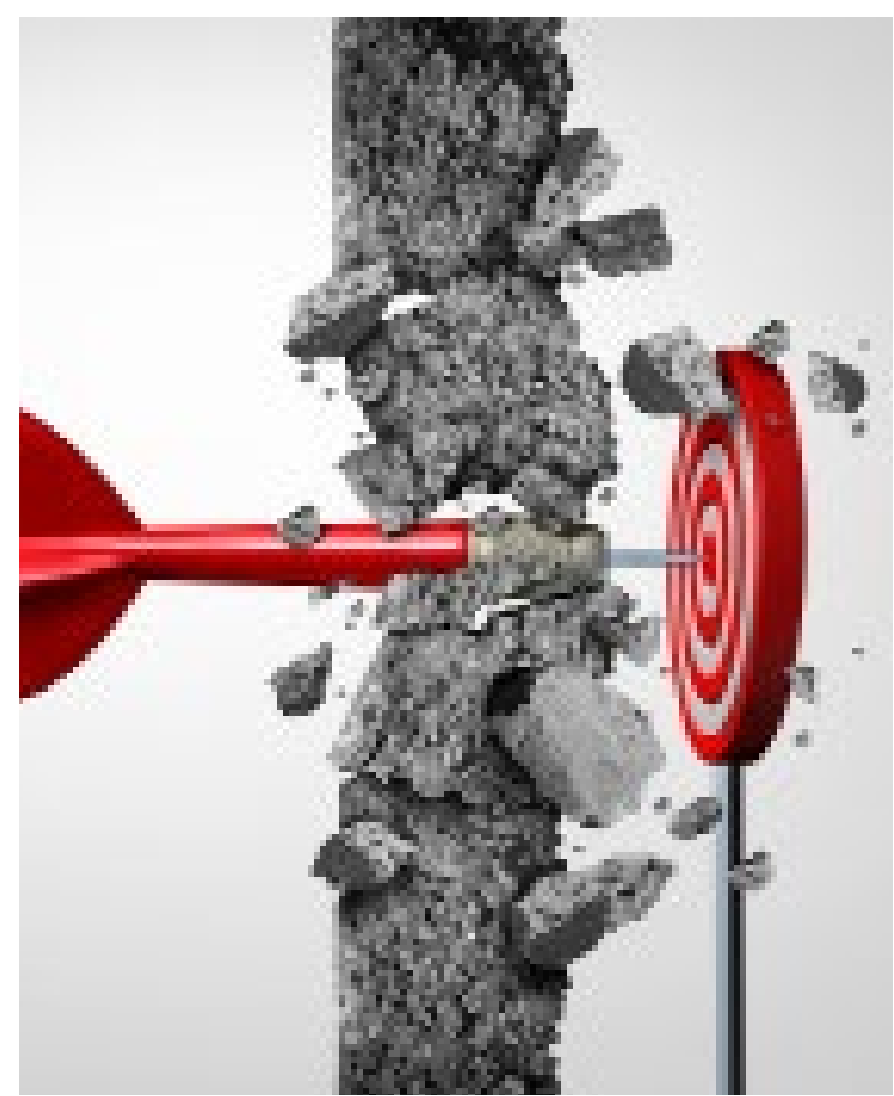

Photo from https://www.physics.com.sg/ 
Five characteristics that have enabled successful leaders to make sacrifices and lead in difficult circumstances provide interesting insights into our investigation and should be considered by youth preparing to take up leadership:

a. the first concerns the ability to be willing. It is imperative for the youth to develop the spirit of volunteerism. A way of attracting opportunity is through volunteerism, as often volunteering schemes are mechanisms put in place to assess one's ability to commit, not because of financial rewards, but because of the satisfaction that comes from positively impacting a life. Experience has shown that most often, doors open to those who have shown willingness to work voluntarily. You may not be paid, but the experience and skills gained will be inestimable. Once the experience gained, the youth must also be careful not to sell herself cheap. There is nothing more demeaning then seeing your skills and potential unvalued through exploitation. One must be professionally assertive with regards to her value and what she brings on board;

b. the second concerns the ability to listen. Most leaders tend to be on the go and rarely quiet themselves enough to listen to anybody, including themselves, their constituents or even the supreme religious entity they believe in. Youth leaders must deliberately arrange for reflection time and grow quiet enough to hear their own voice and that of those they serve - community members, family, mentors, etc. - who are contributing to electing or nominating them to whatever position they are running for;

c. the third concerns the arrogance and cockiness characteristic of those who, by virtue of their leadership, are used to getting what they want. The tendency to hero worship and praise leaders in Africa has created a situation where those who occupy leadership positions become cocky and unaware of their weaknesses. In some cases, they become unaware even of their mortality. It is necessary that the youth who seek to take up leadership humble themselves for service, look at themselves honestly, and admit their weaknesses. This will enable them to become servant leaders, attract people who can compensate for their weaknesses, and demonstrate the difference youth can bring to leadership;

d. the fourth concerns the realisation that none of us, no matter how gifted or talented, can undertake anything worthwhile and make a difference to the quality of the lives of those we serve when we remain staunchly self-reliant. It has been argued that youth are much more relationship oriented than older folks and therefore more likely to consult and be team players. Yet, many youths adopt characteristics and leadership values of the aged or past and current leaders in order to be accepted and to feel they belong;

e. the fifth concerns values and principles the kind of youth we expect to see in leadership are going by. Many are those who think the following ancient values are outdated. But we are talking about leadership here, not politics. Jackie's nine must be embraced by disciplined leaders:

- Courage: doing what you know is right; Commitment: being disciplined and staying on task regardless of the situation and keeping your promises; accountability to the public for decisions and actions;

- Citizenship: being vested with rights and duties and making an example by being part of something better, through how you act and affect others;

- Determination: continuing through difficulty despite what things look like;

- Excellence: staying positive, never giving up, and doing your best, competence, and meritocracy;

- Teamwork: establishing strength together as a whole and focusing on achieving a greater good;

- Justice: the fair treatment of everyone, objectivity and impartiality in decision-making, and in ensuring that decisions are not influenced by nepotism, favouritism, or any other improper motives or corrupt practices (Okombo et al., 2011);

- Persistence: continuing to press forward even though you experience life's challenges; selfless service based solely on the public interest; Integrity: do the right thing even when no one is watching.

The application of these principles goes according to the context and of course, must be smartly put through, depending on who you are facing, the nature of what is in for the people, among other factors and variables. 



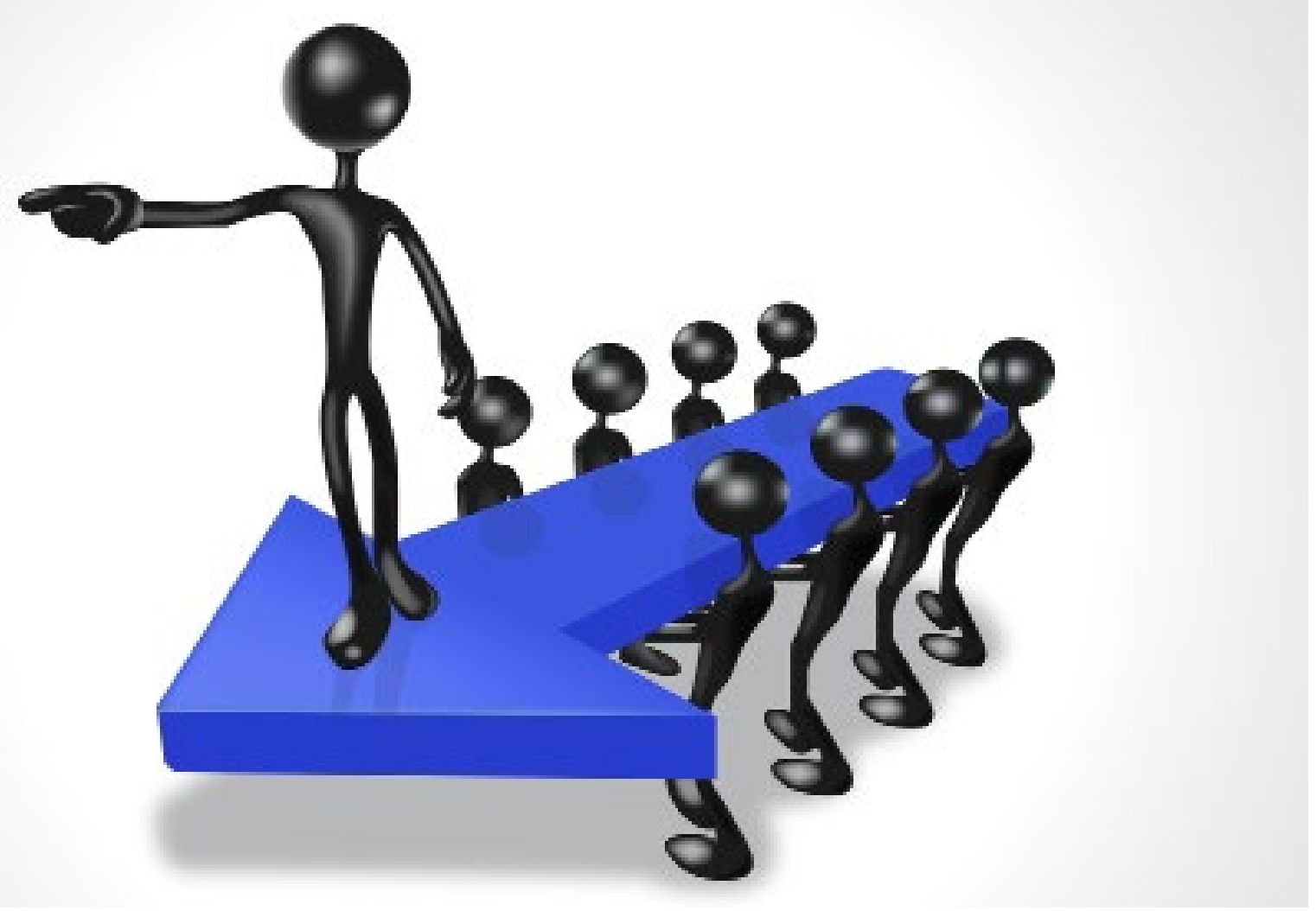

Photo from https://www.jing.fm/

Accordingly, the popular belief that the youth have not contributed much to national development in pre and post-colonial Africa is grossly erroneous. As study has revealed that low level of active youth leadership on the continent is not due to lack of interest and effort on their part, but more because of the hostile political, economic and social environment, rigid structural barriers to youth mobility in politics and the economy in many West African countries. 'Harmful' cultural practices that require young people to defer to older ones make it hard for the youth to 'liberate' themselves (Sesay, 2014). Young people have also not been able to successfully organise themselves into workable pressure groups to effect positive political and economic change in their favour (Sesay, 2014).

Nevertheless, the young people of today are, on average, better educated than their parents. They are better connected to the rest of the world than any of the earlier generations of youth, and they are, as a result, more determined to find options to close the gap between their limited opportunities and what they perceive to be possible in the global sphere. Failure to provide opportunities for youth to build their capacity to participate in development would be a missed opportunity to harness the huge potential in human capital, and this could have enormous economic, cultural, political and social consequences (Kura, 2008).
Equally, as today's old generation was yesterday's youth, it is imperative for young people to not become different as they grow older. Especially, as they experience the realities of power, they are encouraged not to become corrupt themselves and maintain integrity in order not to perpetuate the cycle. They must remain committed to those ideals which they hold valuable when they are young.

Many people change as they get older and sometimes lose sight of why they entered politics in the first place. The youth need family support, high expectations at home and in the community, and exposure to positive leadership role models that will inspire confidence in them and assist them in developing their leadership potential. Last but not the least, the youth must always remember Annan's saying: "you are never too young to lead, and you should never doubt your capacity to triumph where others have not." 


\section{SOURCES AND BIBLIOGRAPHY}

Akwagyiram, A. (2018, April 19). Buhari remarks on young Nigerians' work ethics stirs social media storm. Retriedved March 12, 2020 from Reuters: https://www.reuters.com/article/ us-nigeria-politics/buhari-remarks-on-young-nigerians-workethic-stirs-social-media-storm-idUSKBN1HQ2LR.

Blond, P., Sim, D., \& Noyes, J. (2017, July 12). Britain's global future: Harnessing the soft power capital of uk institutions. Retrieved from https://www.respublica.org.uk/our-work/ publications/britains-global-future-harnessing-soft-powercapital-uk-institutions/

Bodomo, A. (2009). Africa-China Relations: Symmetry, Soft Power and South Africa. China Review, 9 (2), 169-178.

Clement et al. (2014). Youth Civic Engagement and Leadership. Washington: Elliot School of International Affairs and the Child Fund.

Dlamini et al. (2015). Female Youth Participation in the Urban Milieu: Unpacking Barriers and. 5(1): Citizenship Education Research Journal (CERJ).

Gouvernement du Togo. (2020, 10 23). La promotion du leadership feminin porte ses fruits au Togo. Retrieved from https://presidence.gouv.tg/: https://presidence.gouv. $\mathrm{tg} / 2020 / 10 / 23 /$ la-promotion-du-leadership-feminin-porteses-fruits-au-togo/

Guterres, A. (2018). https://www.un.org/sg/en/content/sg/ personnel-appointments/2018-07-12/secretary-generals-highlevel-panel-digital-cooperation

Hachelaf, A. A., (2020), Leadership Development: Fixing a Flat Tire, or Re-inventing the Wheel, WACSeries, Op-Ed N¹4, West Africa Civil Society Institute, Accra, Ghana.

IDEA. (2018). Youth Participation in Political Processes. Stockholm: International Institute for Democracy and Electoral Assistance.

IIED/IDS/PLAN. (2011). Participatory learning and action. International Institute for Environment and Development.

Kanyadudi, C. J. (2010). From the Wings to the Mainstream: The Role of Political Parties Youth Leagues in Democratisation and Regional Integration in East Africa. Nairobi: Friedrich Ebert Stiftung (FES).

Kura, H. K. (2008). Youth and National Development: Opportunities and Challenges. Kampala: Centre for Democratic Research and Training (CDRT), Bayero University, Kano.

Lanshina, T. (2015). The Goethe Institute and Soft Power . International Organisations Research Journal, 10 (1).

National Telegraph Africa. (2020, May 10). Retrieved from Facebook Page.

Oduol, J. A. (2011). Women in Leadership and Good Governance. In J. Kwaka, O. Okombo, B. Muluka, \& B. Sungura-
Nyabuto, Challenging the Rulers: A Leadership Model for Good Governance (p. 299). Kigali: East African Educational Publishers.

Okombo et al. (2011). Challenging the rulers: A leadership model for good governance. East African Educational Publishers Ltd.

Pan, S.-Y. (2013). Confucius Institute project: China's cultural diplomacy and soft power projection. Asian Education and Development Studies, 2(1), 22-33. https://doi. org/10.1108/20463161311297608.

Rahman, S. (2019). China's Foreign Policy and its Choice for Cultural Soft Power:The Tools. Social Change Review, 17, 90-115.

Restless Development. (2014). Youth Participation in Local Council Decision-Making in Sierra Leone: The successes and challenges of decentralised participatory governance from a youth perspective. Restless Development.

Restless Development. (2015). Nurturing Youth Leadership in the Global South: A Mapping of Strategies, Approaches, Challenges and Opportunities. Restless Development.

Sako, S. (2002). Brain Drain and Africa's Development: A Reflection. In P. Zeleza, The African "Brain Drain" to the North: Pitfalls and Possibilities (pp. 30(1),25-30). Cambridge University Press.

Sesay, A. (2014). African Governance Systems in the Pre and Post-Independence Periods: Enduring Lessons and Opportunities for Youth in Africa. Johannesburg: Mandela Institute for Development Studies.

Tracey, L., \& Kahuthia, E. (2017). Beyond Rhetoric: Engaging Africa's youth in democratic governance. Policy Brief 99: Africa Governance Architecture (AGA) and the Institute for Security Studies (ISS).

UN. (2018). World Youth Report: Youth and the 2030 Agenda for Sustainable Development. New York: United Nations.

UNDP. (2012). Enhancing Youth Political Participation throughout the Electoral Cycle (Fact Sheet). New York: United Nations Development Programme.

UNDP. (2014). UNDP youth strategy 2014-2017: Empowered Youth, Sustainable Future. New York: United Nations Development Programme.

UNECA. (2013). African Governance Report 3: Election and the Management of Diversity. New York: United Nations Economic Commission for Africa.

UNESCO. (2002). UNESCO: mainstreaming the needs of youth. Paris: The United Nations Educational, Scientific and Cultural Organization.

WPAY. (2006). Guide to the Implementation of the World Programme of Action for Youth. New York: United Nations. 


\section{WACSI}

Strengthening Civil Society

(c) WACSI 2021 All Rights Reserved. 